\title{
Aeromonas trota strains, which agglutinate with Vibrio cholerae 0139 Bengal antiserum, possess a serologically distinct fimbrial colonization factor
}

\author{
Noboru Nakasone,, Masaaki Iwanaga, ${ }^{1}$ Tetsu Yamashiro, ${ }^{2}$ \\ Kazutoshi Nakashima' and M. John Albert ${ }^{3}$
}

Author for correspondence: Noboru Nakasone. Tel: +81980953331 ext 2287. Fax: +8198 8952951.

\author{
1,2 Department of \\ Bacteriology', and \\ Research Center of \\ Comprehensive \\ Medicine2, Faculty of \\ Medicine, University of \\ the Ryukyus, Okinawa \\ 903-01, Japan \\ 3 International Centre for \\ Diarrhoeal Disease \\ Research, Bangladesh \\ GPO Box 128, Dhaka \\ 1000, Bangladesh
}

\begin{abstract}
Pili of Aeromonas trota strain 1220, which agglutinates with Vibrio cholerae 0139 Bengal antiserum, were purified and characterized. The molecular mass of the subunit protein was estimated to be $20 \mathrm{kDa}$ and the pl was 5.4. The pili were immunologically unrelated to the other Aeromonas pili reported so far. However, the $\mathbf{N}$-terminal amino acid sequence of the subunit pilin was similar to those of the pilins from other Aeromonas pili reported previously. Neither A. trota cells nor pili purified from strain 1220 agglutinated human and rabbit erythrocytes, but both adhered to the rabbit intestine. Bacterial cells pretreated with antipilus antibody (Fab portion) failed to adhere to the rabbit intestine. Moreover, bacteria did not adhere to the rabbit intestine pretreated with the purified pili. This pilus antigen was not detected in V. cholerae 0139 Bengal and other Aeromonas spp. These findings suggest that the pilus of the A. trota strain is a novel colonization factor of Aeromonas spp.
\end{abstract}

Keywords: Aeromonas trota, pili, colonization factor

\section{INTRODUCTION}

Aeromonas spp. have been recognized as important human enteropathogens (Moyer, 1987; Janda, 1991), and a variety of haemagglutinins or colonization factors of these organisms have been reported (Ho et al., 1990; Quinn et al., 1993; Hokama et al., 1990; Hokama \& Iwanaga, 1991, 1992; Iwanaga \& Hokama, 1992). Vibrio cholerae O139 Bengal is a new aetiological agent of cholera which caused large epidemics in the Indian subcontinent in 1992-1993 and spread into neighbouring countries (Albert et al., 1993; Chongsa-nguan et al., 1993). During the epidemic caused by the new cholera organism in Bangladesh, an attempt was made to identify Aeromonas spp. cross-reacting with $V$. cholerae $\mathrm{O} 139$ and several strains of Aeromonas sobria were found to agglutinate with $V$. cholerae $\mathrm{O} 139$ antiserum. The cross-reacting antigens resided in the LPS as demonstrated by the reactivity of the purified LPS with antisera in Western blots (Ansaruzzaman et al., 1994). However, the cross-reacting $A$. sobria strains were subsequently identified as Aeromonas trota in the laboratory of Dr T. Shimada, National Institute of Health, Tokyo, Japan, by standard tests (Carnahan et al., 1991). Strain 1220 is one of the six isolates which agglutinated with the $V$. cholerae $\mathrm{O} 139$ antiserum.
Ansaruzzaman et al. (1994) examined the virulence properties of the Aeromonas isolates and found that all strains produced a cytotoxin for $\mathrm{HeLa}$ cells and adhered to HEp-2 cells. We were interested in characterizing the colonization factor of these unique strains because colonization by pathogens is the first step of the infectious disease process. In this communication, we report the characterization of pili (fimbriae) isolated from one strain.

\section{METHODS}

Bacterial strains. $A$. trota strain 1220 , isolated from surface water in Bangladesh, was used for the purification of pili. This strain is one of the six isolates which agglutinated with $V$. cbolerae O139 antiserum (Ansaruzzaman et al., 1994). The identification characteristics of the isolates included negative reactions for aesculin hydrolysis, arabinose fermentation and the Voges-Proskauer test, positive reactions for cellobiose fermentation, lysine decarboxylation and citrate utilization, and susceptibility to ampicillin (Carnahan et al., 1991). A. sobria strains Ae1, Ae24 and TAP13, A. bydropbila strain Ae6 and other Aeromonas spp. reported previously (Hokama \& Iwanaga, 1991, 1992; Iwanaga \& Hokama, 1992; Hokama et al., 1990), were used for comparison. $V$. cholerae $\mathrm{O} 1$ (El Tor 21, Classical 21), $V$. cholerae $\mathrm{O} 139$ and other serotypes of $V$. cholerae, isolated from diarrhoeal patients, were also used when necessary. 

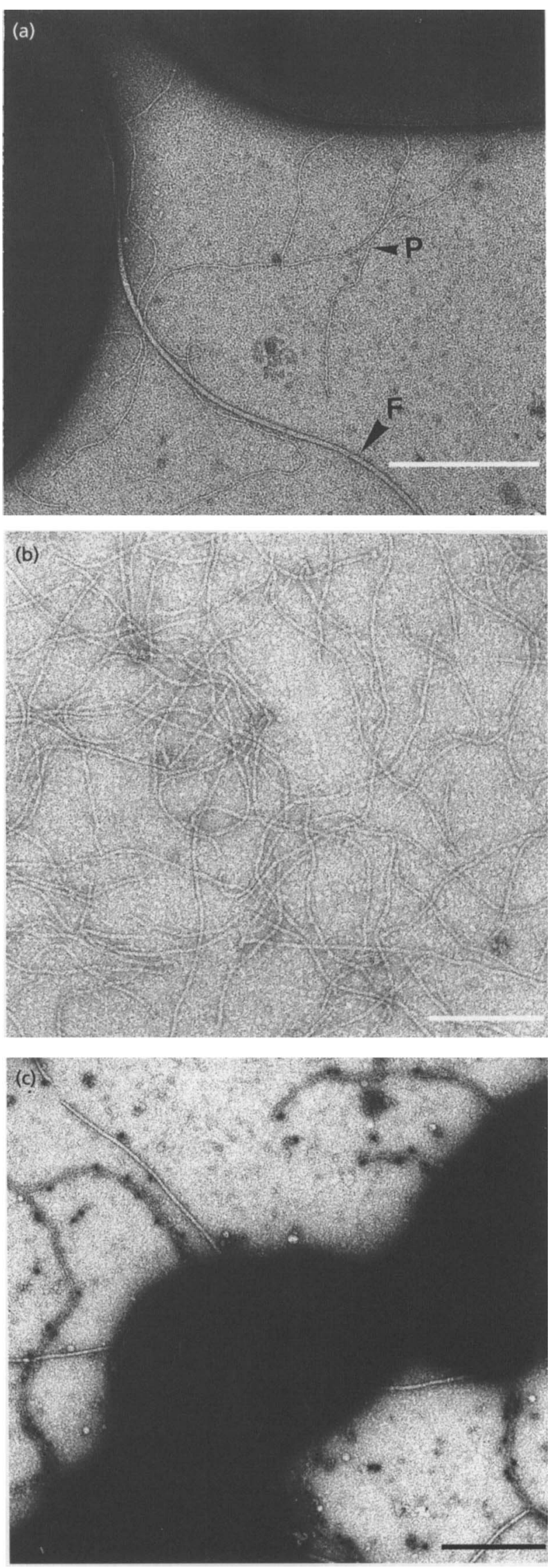

Growth conditions. The organisms, subcultured on a nutrient $(0.5 \%$, w/v, meat extract; $1 \%$, w/v, peptone; $0.5 \%$, w/v, $\mathrm{NaCl}$ ) agar plate, were inoculated into $500 \mathrm{ml}$ Trypticase Soy Broth (Difco) in a 31 Erlenmeyer flask and incubated at $30^{\circ} \mathrm{C}$ for $12 \mathrm{~h}$ with reciprocal shaking.

Purification of pili. The pili were purified according to the method of Honma \& Nakasone (1990) with a slight modification. Briefly, a heavy suspension of the harvested cells in $50 \mathrm{mM}$ Tris/ $\mathrm{HCl}$ buffer, $\mathrm{pH} 8.0$, was agitated in a biomixer (Nihon Seiki) for $5 \mathrm{~min}$, and centrifuged at $26000 \mathrm{~g}$ for $30 \mathrm{~min}$. $\mathrm{NaCl}$ and PEG 6000 (Wako Chemical) were added to the supernatant fraction (final concentrations of $5.8 \%, \mathrm{w} / \mathrm{v}$, and $2 \%, \mathrm{w} / \mathrm{v}$, respectively). The mixture was incubated for $30 \mathrm{~min}$ with stirring, and then centrifuged at $15000 \mathrm{~g}$ for $30 \mathrm{~min}$. PEG was further added to the supernatant fraction to make the final concentration $6 \%(\mathrm{w} / \mathrm{v})$, and the mixture was incubated overnight at $4{ }^{\circ} \mathrm{C}$. Pili-rich material which precipitated was collected by centrifugation at $15000 \mathrm{~g}$ for $30 \mathrm{~min}$. The pili were purified by $60-10 \%$ sucrose density gradient centrifugation $(15200 \mathrm{~g}, 2 \mathrm{~h})$.

Protein assay. The protein content was assayed using the BioRad protein kit with BSA as the standard.

Electrophoresis. SDS-PAGE was performed by the method of Laemmli (1970) with $12 \%(\mathrm{w} / \mathrm{v})$ polyacrylamide gels. The isoelectric point of the purified pili was determined by the method of O'Farrell (1975) with prestained pI markers as standards (Oriental Kobo).

Preparation of antibody. Antipilus antiserum was prepared by immunizing Japanese White rabbits. Two doses, each containing $100 \mu \mathrm{g}$ purified pili protein, were given as multiple subcutaneous injections 2 weeks apart. The first dose was emulsified with Freund's complete adjuvant, the booster dose with incomplete adjuvant. The Fab fraction of antibody was prepared as described previously (Iwanaga \& Hokama, 1992).

Haemagglutination test. The haemagglutinating activities of A. trota (strain 1220) cells and of the purified pili were examined with human group A and rabbit erythrocytes (Iwanaga \& Hokama, 1992).

Adhesion test. The ability of the organisms to adhere to rabbit intestinal epithelium was examined by the MASK method (Nakasone \& Iwanaga, 1987). Briefly, formalin-fixed intestine was incubated in the bacterial suspension [about $10^{9}$ cells $\mathrm{ml}^{-1}$ in Krebs-Tris-Ringer's buffer (KRT: $128 \mathrm{mM} \mathrm{NaCl}, 5.1 \mathrm{mM}$ $\left.\mathrm{KCl}, 1.34 \mathrm{mM} \mathrm{MgSO}_{4} .7 \mathrm{H}_{2} \mathrm{O}\right), 2.7 \mathrm{mM} \mathrm{CaCl}_{2}, 10 \mathrm{mM}$ Tris $/ \mathrm{HCl}$ buffer, $\mathrm{pH} \mathrm{7 \cdot 4)]} \mathrm{for} 10 \mathrm{~min}$ at $30^{\circ} \mathrm{C}$, then vigorously washed with KRT buffer. The sample was prepared for scanning electron microscopy. Adherent organisms were counted in 30 randomly selected scanning electron microscope fields at $\times 4000$ magnification. The adhesion index was expressed as the mean of the count per field.

Fig. 1. Transmission electron micrographs of (a) A. trota strain 1220 cells showing flexible pili (P) and a flagellum (F) (bar, $500 \mathrm{~nm}$ ) and (b) purified pili from A. trota strain 1220 (bar, $200 \mathrm{~nm}$ ). (c) Transmission electron micrograph of $A$. trota strain 1220 examined by using the immunogold-labelled Protein $A$. Cells were incubated with rabbit anti-A. trota pilus antiserum and then with Protein A conjugated with $15 \mathrm{~nm}$ colloidal gold particles. The gold particles bound specifically along the length of the pili. Note that pili reacting with the antibody appear distended. Bar, $500 \mathrm{~nm}$. Preparations were negatively stained with $4 \%$ uranyl acetate. 
Adhesion inhibition test. Two kinds of pretreatment were performed before the adhesion test. Briefly, in the first method, the organisms were treated with the Fab fraction of either IgG from nonimmunized rabbits or antipilus antibody at $30^{\circ} \mathrm{C}$ for $30 \mathrm{~min}$ and then the adhesion test was performed using the intact rabbit intestine. In the second method, intestinal epithelium pretreated in the purified pilus suspension at $30^{\circ} \mathrm{C}$ for $30 \mathrm{~min}$ to block the receptor was exposed to the bacterial cells (Iwanaga \& Hokama, 1992).

Immunological techniques. Western blotting was performed as described by Towbin et al. (1979). A 1:200 dilution of antipilus serum was used as the first antibody. Electron microscopic immunogold labelling to confirm the specificity of the antiserum and immunohistochemical examination to detect the adhered pili on the surface of the rabbit intestinal epithelium were performed as described previously by Iwanaga \& Hokama (1992). Slide agglutination tests were carried out using agargrown organisms and antipilus serum to study the distribution of the pilus-associated antigen.

Electron microscopy. $A$. trota cells and purified pili were negatively stained with $4 \%(\mathrm{w} / \mathrm{v})$ uranyl acetate on carboncoated Formvar grids and observed with a JEM 2000EX transmission electron microscope. Organisms adherent to the rabbit intestinal villi were observed with a Hitachi S450 scanning electron microscope. The samples were prepared as described previously by Nakasone \& Iwanaga (1987).

Amino acid sequence. The $\mathrm{N}$-terminal amino acid sequence of the strain 1220 pili was analysed by automated Edman degradation on a Shimadzu PSQ-1 protein sequencer.

\section{RESULTS}

On electron microscopy, $A$. trota strain 1220 was found to have long, flexible pili with a diameter of about $7 \mathrm{~nm}$ (Fig. 1a). In the pili purification protocol used, flagella and cell debris were precipitated with $2 \%$ (w/v) PEG. In the precipitates obtained with $6 \%(\mathrm{w} / \mathrm{v})$ PEG, the pili were almost pure. Finally, after sucrose density gradient centrifugation, about $250 \mu \mathrm{g}$ purified pili was obtained from 21 culture. Electron microscopy of the negatively stained preparations demonstrated that the purified pili were of flexible appearance with a diameter of about $7 \mathrm{~nm}$ as seen on the cell surface (Fig. 1b).

The subunit protein of the pili (pilin) migrated as a single molecular species in SDS-PAGE. The molecular mass was estimated to be about $20 \mathrm{kDa}$. Isoelectric focusing revealed the $\mathrm{pI}$ to be about $5 \cdot 4$. The $\mathrm{N}$-terminal amino acid sequence of the $A$. trota pilin was highly similar to those of other Aeromonas pilins reported previously (Table 1).

The agglutination titre of the antipilus antibody obtained by immunizing rabbits was $1: 2048$ in a serial test-tube dilution method using live organisms. The antibody was highly specific for the pilin because the antiserum reacted only with the $20 \mathrm{kDa}$ protein of whole-cell lysate as examined by Western blotting. Also in the immunogold electron microscopy analysis, the antibody bound to the pili on bacteria but not to flagella or outer-membrane debris (Fig. 1c).

The distribution of the $A$. trota strain 1220 pilusassociated antigen in other organisms was examined by agglutination and by Western blotting of whole-cell lysates. None of the 103 Aeromonas strains (47 A. bydrophila, $45 \mathrm{~A}$. sobria and $11 \mathrm{~A}$. caviae), and none of the $64 \mathrm{~V}$. cholerae strains (42 O1, $8 \mathrm{O} 139$ and 14 strains of other serovars) possessed this pili-associated antigen. However, all six strains of $A$. trota which cross-reacted with the $V$. cholerae $\mathrm{O} 139$ antiserum were positive for this pili-associated antigen. The other Aeromonas pilus antisera which we have previously reported (Hokama \& Iwanaga, 1991, 1992; Iwanaga \& Hokama, 1992; Hokama et al., 1990) did not react with the 1220 pili.

A. trota cells and purified pili did not agglutinate human group $\mathrm{A}$ and rabbit erythrocytes. The live cells of $A$. trota adhered strongly to the rabbit intestine (Fig. 2). The purified pili also adhered to the rabbit intestine as examined by an enzyme-labelled antibody technique (data not shown). Pili-like structures were observed on the organisms attaching to the rabbit intestinal epithelial

\section{Table 1. N-terminal amino acid sequences and molecular masses of Aeromonas and other bacterial pilins}

The sequences and molecular mass of the pilins of $A$. sobria Ae1 (Hokama \& Iwanaga, 1991), TAP13 (Iwananga \& Hokama, 1992) and Ae24 (Hokama \& Iwanaga, 1992), A. bydrophila Ae6W (Hokama \& Iwanaga, 1991), V. cholerae TCP (Taylor et al., 1987), Neisseria gonorrboeae (Hermodson et al., 1978) and Pseudomonas aeruginosa (Sastry et al., 1983) are presented for comparison. Residues are presented in the one-letter code.

\begin{tabular}{|c|c|c|}
\hline Pilin & $\begin{array}{c}\text { N-terminal amino acid } \\
\text { sequence }\end{array}$ & $\begin{array}{c}\text { Molecular } \\
\text { mass (kDa) }\end{array}$ \\
\hline A. trota strain 1220 & Y T L I E L V IVIIIL G I L A V T A A PKFL & 20 \\
\hline A. sobria Ae1 & M T L I E L V I V I & 23 \\
\hline A. sobria TAP13 & Y T L I E L V I V I I I L G I L A & 23 \\
\hline A. sobria Ae24 & Y T L I E L V I V I I I L G I L A D D A & 19 \\
\hline A. bydropbila Ae6W & M T L I E L V I V I & 21 \\
\hline V. cholerae TCP & MeF T L L E VIIVL L G I M GVVSA GV V & $20 \cdot 5$ \\
\hline N. gonorrboeae & MeF T L I E L M I I A I V G I L A A A L P A Q & 18 \\
\hline$P$. aeruginosa & MeF T L I E L M IV V I I G I L A A I I PQ & 18 \\
\hline
\end{tabular}




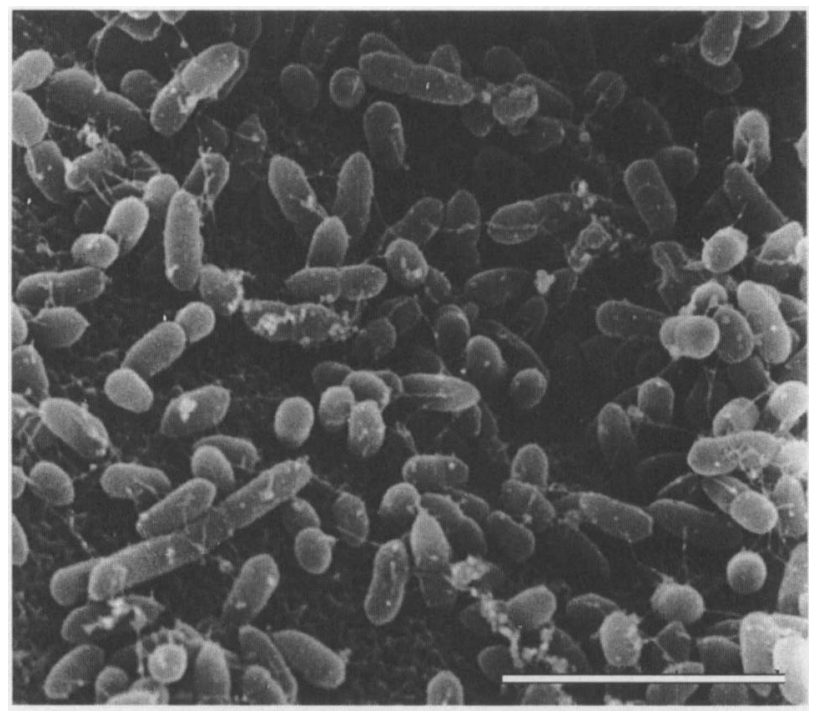

Fig. 2. Scanning electron micrograph of $A$. trota 1220 cells adhering to rabbit intestinal epithelium. Preparations were formalin-fixed. Bar, $50 \mu \mathrm{m}$.

Table 2. Adhesion and adhesion-inhibition tests of A. trota (strain 1220) cells to the rabbit intestinal epithelium

\begin{tabular}{|lc|}
\hline $\begin{array}{l}\text { Pretreatment of the intestine } \\
\text { or the organisms with: }\end{array}$ & Adhesion index* \\
\hline Pili $\left(\mu \mathrm{g} \mathrm{ml}^{-1}\right)$ & \\
0 & $119 \pm 60$ \\
85 & $92 \pm 39$ \\
170 & $47 \pm 36$ \\
255 & $53 \pm 41$ \\
350 & $58 \pm 43$ \\
Fab portion of antipilus antibody $\left(\mathrm{mg} \mathrm{ml}^{-\mathbf{1}}\right)$ & \\
0 & $131 \pm 55$ \\
$0 \cdot 5$ & $104 \pm 37$ \\
1 & $24 \pm 21$ \\
3 & $25 \pm 25$ \\
Fab portion of control antibody $\left(\mathrm{mg} \mathrm{ml}^{-\mathbf{1}}\right)$ & $131 \pm 61$ \\
3 & \\
\hline
\end{tabular}

* Numbers of adherent organisms per field (mean \pm sD of 30 fields). Control antibody was obtained from preimmune sera of rabbits.

surface (Fig. 2). The adhesion index of this organism was about 130 .

The adhesion-inhibition test with pretreatment of the intestinal epithelium with purified pili to block the receptors revealed dose-dependent inhibition; up to a $50 \%$ decrease in the adherence of organisms was observed (Table 2). Pretreatment of the $A$. trota cells with antipilus antibody also blocked the adherence of the organisms in a dose-dependent manner; up to an $80 \%$ decrease in adherence was observed (Table 2). Both blocking tests failed to completely inhibit adhesion. The Fab portion of IgG antibody from preimmune sera of rabbits failed to inhibit adhesion.

\section{DISCUSSION}

The pili purified from $A$. trota (strain 1220) were identified as a colonizing factor of the strain, but they had no relation to $V$. cholerae O139 components. Previously, we examined the properties of adhesion of $V$. cholerae and Aeromonas species to the human intestine and the rabbit intestine and found that they adhered equally well to both intestines (Yamamoto et al., 1988; Hokama \& Iwanaga, 1991). In the present study, we have used the rabbit intestine and found that it was a satisfactory system for $A$. trota attachment studies. It is noteworthy that the flexible pili of Aeromonas species were all identified as colonization factors (Hokama et al., 1990; Hokama \& Iwanaga, 1991; Iwanaga \& Hokama, 1992), but the flexible pili of $V$. cholerae were not (Iwanaga et al., 1989; Nakasone \& Iwanaga, 1993). Although the $\mathrm{N}$-terminal amino acid sequences of the pilin subunits of Aeromonas flexible pili are highly similar, the $\mathrm{N}$-terminal residue is a methylated phenylanaline in type 4 pilin in $V$. cholerae, but it is methionine or tyrosine in Aeromonas spp. A unique flexible pilus reported by Ho et al. (1990) has a different amino acid sequence. The flexible pili of Aeromonas so far reported are distributed in $10-30 \%$ of the organisms belonging to the same genus (Hokama et al., 1990; Hokama \& Iwanaga, 1991, 1992; Iwanaga \& Hokama, 1992). However, the pili of $A$. trota (strain 1220) were found only in the six strains that shared somatic antigen with $V$. cholerae O139. Since Aeromonas species have a variety of haemagglutinins (Atkinson et al., 1987) and colonization factors as described above, it may be difficult to develop vaccines using these factors.

\section{REFERENCES}

Albert, M. J., Ansaruzzaman, M., Bardhan, P. K., Faruque, A. S. G. Faruque, S. M., Islam, M. S., Mahalanabis, D., Sack, R. B., Salam, M. A., Siddique, A. K., Yunus, M. D. \& Zaman, K. (1993). Large epidemic of cholera-like disease in Bangladesh caused by Vibrio cholerae O139 synonym Bengal. Lancet 342, 387-390.

Ansaruzzaman, M., Rahman, A., Alam, K., Islam, M. S., Qadri, F. \& Albert, M. J. (1994). Some strains of Aeromonas sobria share somatic (O) antigen with Vibrio cholerae O139 Bengal. In The 30th Joint Conference of the US-Japan Cooperative Medical Science Program on Cholera and Related Diarrheal Diseases Panel, pp. 46-51. Edited by K. Amako \& R. L. Guerrant. Fukuoka: Japan.

Atkinson, H. M., Adams, D., Savvas, R. S. \& Trust, T. J. (1987). Aeromonas adhesin antigens. Experientia 43, 372-374.

Carnahan, A. M., Chakraborty, T., Fanning, G. R., Verma, D., Ali, A., Janda, J. M. \& Joseph, S. W. (1991). Aeromonas trota sp. nov., an ampicillin-susceptible species isolated from clinical specimens. J Clin Microbiol 29, 1206-1210.

Chongsa-nguan, M., Chaicumpa, W., Moolasart, P., Kandhasingha, P., Shimada, T., Kurazono, H. \& Takeda, Y. (1993). Vibrio cholerae O139 Bengal in Bangkok. Lancet 342, 430-431.

Hermodson, M. A., Chen, K. C. S. \& Buchanan, T. M. (1978). Neisseria pili proteins: amino-terminal amino acid sequences and identification of an unusual amino acid. Biocbemistry 17, 442-445. 
Ho, A. S. Y., Mietzner, T. A., Smith, A. J. \& Schoolnik, G. K. (1990). The pili of Aeromonas bydrophila: identification of an environmentally regulated 'mini pilin'. J Exp Med 172, 795-806.

Hokama, A. \& Iwanaga, M. (1991). Purification and characterization of Aeromonas sobria pili, a possible colonization factor. Infect Immun 59, 3478-3483.

Hokama, A. \& Iwanaga, M. (1992). Purification and characterization of Aeromonas sobria Ae24 pili: a possible new colonization factor. Microb Pathog 13, 325-334.

Hokama, A., Honma, Y. \& Nakasone, N. (1990). Pili of an Aeromonas bydrophila strain as a possible colonization factor. Microbiol Immunol 34, 901-915.

Honma, Y. \& Nakasone, N. (1990). Pili of Aeromonas bydrophila: purification, characterization, and biological role. Microbiol Immunol 34, 83-98.

Iwanaga, M. \& Hokama, A. (1992). Characterization of Aeromonas sobria TAP13 pili: a possible new colonization factor. $J$ Gen Microbiol 138, 1913-1919.

Iwanaga, M., Nakasone, N. \& Ehara, M. (1989). Pili of Vibrio cholerae $\mathrm{O} 1$ biotype El Tor: a comparative study on adhesive and non-adhesive strains. Microbiol Immunol 33, 1-9.

Janda, J. M. (1991). Recent advances in the study of the taxonomy, pathogenicity, and infectious syndromes associated with the genus Aeromonas. Clin Microbiol Rev 4, 397-410.

Laemmli, U. K. (1970). Cleavage of structural proteins during the assembly of the head of bacteriophage T4. Nature 227, 680-685.

Moyer, N. P. (1987). Clinical significance of Aeromonas species isolated from patients with diarrhea. J Clin Microbiol 25, 2044- 2048.

Nakasone, N. \& Iwanaga, M. (1987). Quantitative evaluation of colonizing ability of Vibrio cholerae O1. Microbiol Immunol 31, 753-761.

Nakasone, N. \& Iwanaga, M. (1993). Cell-associated hemagglutinin of classical $V$ ibrio cholerae $\mathrm{O} 1$ with reference to intestinal adhesion. FEMS Microbiol Lett 113, 67-70.

O'Farrell, P. H. (1975). High resolution two-dimensional electrophoresis of proteins. J Biol Chem 250, 4007-4021.

Quinn, D. M., Wong, C. Y. F., Atkinson, H. M. \& Flower, R. L. P. (1993). Isolation of carbohydrate-reactive outer membrane proteins of Aeromonas bydropbila. Infect Immun 61, 371-377.

Sastry, P. A., Pearlstone, J. R., Smillie, L. B. \& Paranchych, W. (1983). Amino acid sequence of pilin isolated from Pseudomonas aeruginosa PAK. FEBS Lett 151, 253-256.

Taylor, R. K., Miller, V. L., Furlong, D. B. \& Mekalanos, J. J. (1987). Use of pho $A$ gene fusions to identify a pilus colonization factor coordinately regulated with cholera toxin. Proc Natl Acad Sci US A 84, 2833-2837.

Towbin, H., Staehelin, T. \& Gordon, J. (1979). Electrophoretic transfer of proteins from polyacrylamide gels to nitrocellulose sheets: procedure and some applications. Proc Natl Acad Sci USA 76, 4350-4354.

Yamamoto, T., Kamano, T., Uchimura, M., Iwanaga, M. \& Yokota, T. (1988). Vibrio cbolerae $\mathrm{O} 1$ adherence to villi and lymphoid follicle epithelium: in vitro model using formalin-treated human small intestine and correlation between adherence and cell-associated hemagglutinin levels. Infect Immun 56, 3241-3250.

Received 19 June 1995; revised 18 September 1995; accepted 28 September 1995. 